\title{
Fuzzy logic based plantwide control applied to ethanol production from potato
}

\section{starch}

Article Info:

Article history: Received 2021-12-16 / Accepted 2022-01-20 / Available online 2022-01-20

doi: 10.18540/jcecvl8iss 1pp13650-01-16e

Amanda Fonseca Oliveira

ORCID: https://orcid.org/0000-0002-0292-5379

Federal University of Sergipe, Brazil

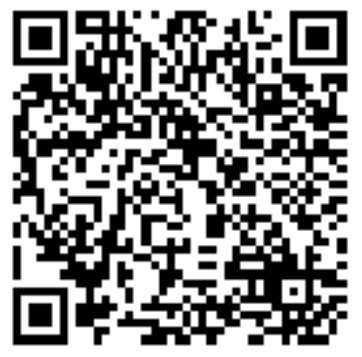

E-mail: amandafonseca888@gmail.com

Félix Rezende Santos

ORCID: https://orcid.org/0000-0002-3932-4219

Federal University of Sergipe, Brazil

E-mail: felix.rezende@gmail.com

Rodolpho Rodrigues Fonseca

ORCID: https://orcid.org/0000-0002-5831-7460

Federal University of Sergipe, Brazil

E-mail: rodolphorf@academico.ufs.br

\begin{abstract}
Industrial plants dedicated to ethanol production have a large number of interrelated processes and operations with nonlinear dynamics, requiring a process control design method considering plantwide aspects and nonlinear control techniques application, as fuzzy logic, to overcome disturbance effects on process control performance. In this work, disturbance in an ethanol process plant were investigated in order to propose a fuzzy system to improve the plantwide control and keep process productivity. The fuzzy system was set to adapt the bioreactor temperature setpoint in case of disturbances, avoiding process deregulation. The results indicated that the fuzzy system developed was able to improve plantwide process control performance and also increasing process productivity.
\end{abstract}

Keywords: Plantwide Control. Fuzzy Logic. Ethanol production.

\section{Nomenclature}

$\Delta \mathrm{u}$ - Variation of the controller outputs

$\tau_{I}-$ Integral time constant of a PID controller

$\mathrm{C}_{\mathrm{A}, \mathrm{i}}-$ Starch concentration in enzymatic reactor input flow $\left[\mathrm{kg} / \mathrm{m}^{3}\right]$

$\mathrm{C}_{\mathrm{A}}-$ Starch concentration in enzymatic reactor $\left[\mathrm{kg} / \mathrm{m}^{3}\right]$

$\mathrm{C}_{\mathrm{A}, \mathrm{F}}-$ Starch concentration in bioreactor $\left[\mathrm{kg} / \mathrm{m}^{3}\right]$

$\mathrm{C}_{\mathrm{E}}-$ Enzyme activity in enzymatic reactor $\left[\mathrm{U} / \mathrm{m}^{3}\right]$

$\mathrm{C}_{\mathrm{E}, \mathrm{i}}-$ Enzyme activity in enzymatic reactor input flow $\left[\mathrm{U} / \mathrm{m}^{3}\right]$

$\mathrm{C}_{\mathrm{E}, \mathrm{F}}-$ Enzyme activity in bioreactor $\left[\mathrm{U} / \mathrm{m}^{3}\right]$

$\mathrm{CE}_{\mathrm{j}}-$ Control effort for process variable $j$ control loop

$\mathrm{C}_{\mathrm{P}}-$ Product concentration in bioreactor $\left[\mathrm{kg} / \mathrm{m}^{3}\right]$

$\mathrm{C}_{\mathrm{S}}$ - Glucose concentration in bioreactor $\left[\mathrm{kg} / \mathrm{m}^{3}\right]$

$\mathrm{C}_{\mathrm{S} 1}-$ Glucose concentration in enzymatic reactor $\left[\mathrm{kg} / \mathrm{m}^{3}\right]$

$\mathrm{C}_{X}-$ Cell concentration in bioreactor $\left[\mathrm{kg} / \mathrm{m}^{3}\right]$

$\mathrm{C}_{\mathrm{X}, \mathrm{C}}-$ Cell concentration in recycle tank input flow $\left[\mathrm{kg} / \mathrm{m}^{3}\right]$

$\mathrm{C}_{\mathrm{X}, \mathrm{R}}-$ Cell concentration in recycle tank $\left[\mathrm{kg} / \mathrm{m}^{3}\right]$

$\mathrm{e}(\mathrm{t})$ - Process variable error 
$F_{A}-$ Starch input flow in enzymatic reactor $\left[\mathrm{m}^{3} / \mathrm{h}\right]$

$\mathrm{F}_{\mathrm{AG}}-$ Water input flow in recycle tank $\left[\mathrm{m}^{3} / \mathrm{h}\right]$

$\mathrm{F}_{\mathrm{C}}-$ Cell input flow in recycle tank $\left[\mathrm{m}^{3} / \mathrm{h}\right]$

$\mathrm{F}_{\mathrm{D}}$ - Recycle tank discharge $\left[\mathrm{m}^{3} / \mathrm{h}\right]$

$\mathrm{F}_{\mathrm{E}}-$ Enzyme solution input flow in enzymatic reactor $\left[\mathrm{m}^{3} / \mathrm{h}\right]$

$\mathrm{F}_{\mathrm{P}}-$ Bioreactor output flow $\left[\mathrm{m}^{3} / \mathrm{h}\right]$

$F_{R}-$ Cell recycle flow $\left[\mathrm{m}^{3} / \mathrm{h}\right]$

$\mathrm{F}_{\mathrm{S}}$ - Enzymatic bioreactor output flow $\left[\mathrm{m}^{3} / \mathrm{h}\right]$

$\mathrm{F}_{\mathrm{U}}$ - Utility flow $\left[\mathrm{m}^{3} / \mathrm{h}\right]$

$\mathrm{IAE}_{\mathrm{j}}-$ Integral of absolute error for process variable $j$

$\mathrm{K}_{\mathrm{C}}$ - Proportional gain of PID controller

$\mathrm{L}_{\mathrm{F}}-$ Bioreactor liquid level [m]

$\mathrm{L}_{\mathrm{R}}-$ Recycle tank liquid level [m]

$\mathrm{L}_{\mathrm{S}}$ - Enzymatic reactor liquid level [m]

PV - Process variable

$\mathrm{SP}-$ Set point

$\mathrm{T}_{\mathrm{R}}-$ Bioreactor temperature $\left[{ }^{\circ} \mathrm{C}\right]$

$\mathrm{T}_{\mathrm{U}, \mathrm{i}}-$ Input utility temperature $\left[{ }^{\circ} \mathrm{C}\right]$

$\mathrm{T}_{\mathrm{U}}$ - Output utility temperature $\left[{ }^{\circ} \mathrm{C}\right]$

$\mathrm{u}_{\mathrm{i}}-$ Control signal output at instant $i$

$\mathrm{u}_{\mathrm{i}-1}-$ Control signal output at instant $i-1$

$\mathrm{M}_{\mathrm{P}}-$ Product mass production $[\mathrm{kg}]$

\section{Introduction}

With the growing concern regarding the environment, carbon emissions, waste disposal and global warming, as recently discussed during UN Climate Change Conference at Glasgow, environmental friendly fuels and products have gained much prominence. Ethanol, for example, is a biofuel that has great versatility once it can be produced using sustainable resources as sugar cane, corn, beet or even biomass residues like sugar cane bagasse (Lin and Tanaka, 2006). These bioresources provide the carbon source for ethanol fermentation process in different ways like saccharides, starches or cellulosic form (Oliveira et al., 2012).

The potato, an example of starchy source, has gained prominence due to the great waste to which its commercialization generates, being about 25 to $30 \%$ of the potato produced in the world wasted in the form of scrap by appearance defects that compromise its sale (Jasper, 2019).

From the ethanol production point of view, the process must have a fermentation step to convert the substrate into ethanol. However, if the substrate is a starchy source, it requires a hydrolysis step to convert the starch into glucose that can be used by yeast to produce ethanol (Polakovic and Bryjac, 2004; Riaz et al., 2012). Nonetheless, at the fermentation step, cell recovery can also be performed (Ochoa et al., 2010a), keeping a high yeast concentration in attempt to improve process productivity. It can be seen that ethanol production requires multiples steps which, in large scale, indicates the necessity of many equipments and unit operations, making its operation complex and defiant. Thus, an industrial plant has to be well designed to allow a safe and economically feasible production, and one of the main factors that contribute to achieve this goal is the process control. Such application generates several improvements in the process, such as greater productivity, lower risk of human error or accidents, less waste of raw materials, higher energetic efficiency, greater standardization of products, ensuring compliance to specifications and quality. However, large industrial plants are difficult to control only considering isolated operating units, being necessary to consider aspects of plantwide control during the automation system design (Luyben et al., 1998). 
Since the pioneer study on plantwide control developed by Downs and Vogel (1993), many papers have been published reporting different applications and technologies to improve plantwide control (Da Silva et al., 2021; Jahanshahi et al., 2020; Luyben, 2019), even applied to ethanol production (Ochoa et al., 2010a; Ochoa et al., 2010b). Combined to the complexity of large industrial plants operation, in most cases the industrial processes have nonlinear dynamics, which makes the control of such systems even more difficult (Chai et al., 2014). For nonlinear and complex processes control, there are also many published papers showing different techniques able to overcome process nonlinearity during process control design, however there is one that stands-out among them and has been widely used, the fuzzy logic (Castillo and Melin, 2021; Huo et al., 2020; Precup and Hellendoorn, 2011).

Process control using fuzzy logic is based on specialist knowledge about the process, represented as a logic model, which performs a human decision making during process control. The logic model is condensed into a set of heuristic rules that with the help of the fuzzy set theory transposes such linguistic control rules in a coherent control strategy (Batista and Meneghetti, 2018). Therefore, such specialist system is able to efficiently control nonlinear processes, and that is the reason it has been widely used for bioprocess control (Fonseca et al., 2018; Waewsak, et al., 2010; Babuska et al., 2002).

In this scenario, the present work proposes the application of fuzzy logic to improve the plantwide control of an ethanol production plant containing a continuous bioreactor with cell recycle system and an enzymatic reactor for starch hydrolysis. Two different plantwide control structures were evaluated for comparison purposes, being one a plantwide control with feedback control loops configured with PID, and a second plantwide control structure with the same feedback control loops but with a fuzzy logic system to reconfigure bioreactor temperature setpoint considering process disturbances, in order to improve process control and productivity. Both control structures were evaluated using performance criteria IAE, CE and ethanol mass production to establish the advantage in using the specialist system in plantwide control.

\section{Methodology}

\subsection{Ethanol process control}

The ethanol plant simulation was implemented in MatLab/Simulink using the model adapted from Nagy (2007) and Fonseca et al. (2014), as described in appendix. With this process model, a plantwide control system using feedback control loops with PID was proposed according to Luyben et al. (1998). For simplicity, this plantwide control structure is hereby called PCS and is shown in Figure 1. The PID controllers were implemented with anti-reset wind up and tracking time constant equal to 1.5 in all control loops. They were also tuned using the relay method (Seborg et al., 2004) followed by a fine tune in order to improve process dynamic response.

For $\mathrm{L}_{S}, \mathrm{~L}_{\mathrm{F}}$ and $\mathrm{L}_{\mathrm{R}}$ control loops, purely proportional $(\mathrm{P})$ control law was used whereas the control loops of $\mathrm{C}_{\mathrm{S} 1}, \mathrm{C}_{\mathrm{P}}, \mathrm{C}_{\mathrm{X}, \mathrm{R}}$, and $\mathrm{T}_{\mathrm{R}}$, were configured with a proportional and integral (PI) control law to avoid the presence of permanent error. Table 1 presents the tuning parameters used.

Table 1 - PID tuning parameters.

\begin{tabular}{cccc}
\hline Process Variable & Controller Tag & $K_{C}$ & $\tau_{I}$ \\
\hline $\mathrm{C}_{\mathrm{S} 1}$ & $\mathrm{AC01}$ & 3.75 & 6.25 \\
$\mathrm{C}_{\mathrm{P}}$ & $\mathrm{AC03}$ & 2 & 4 \\
$\mathrm{C}_{\mathrm{X}, \mathrm{R}}$ & $\mathrm{AC07}$ & 3.3 & 11 \\
$\mathrm{~T}_{\mathrm{R}}$ & $\mathrm{TC0}$ & 1.2 & 0.8 \\
$\mathrm{~L}_{\mathrm{S}}$ & $\mathrm{LC02}$ & 150 & $\infty$ \\
$\mathrm{L}_{\mathrm{F}}$ & $\mathrm{LC} 06$ & 135 & $\infty$ \\
$\mathrm{L}_{\mathrm{R}}$ & $\mathrm{LC05}$ & 300 & $\infty$ \\
\hline
\end{tabular}




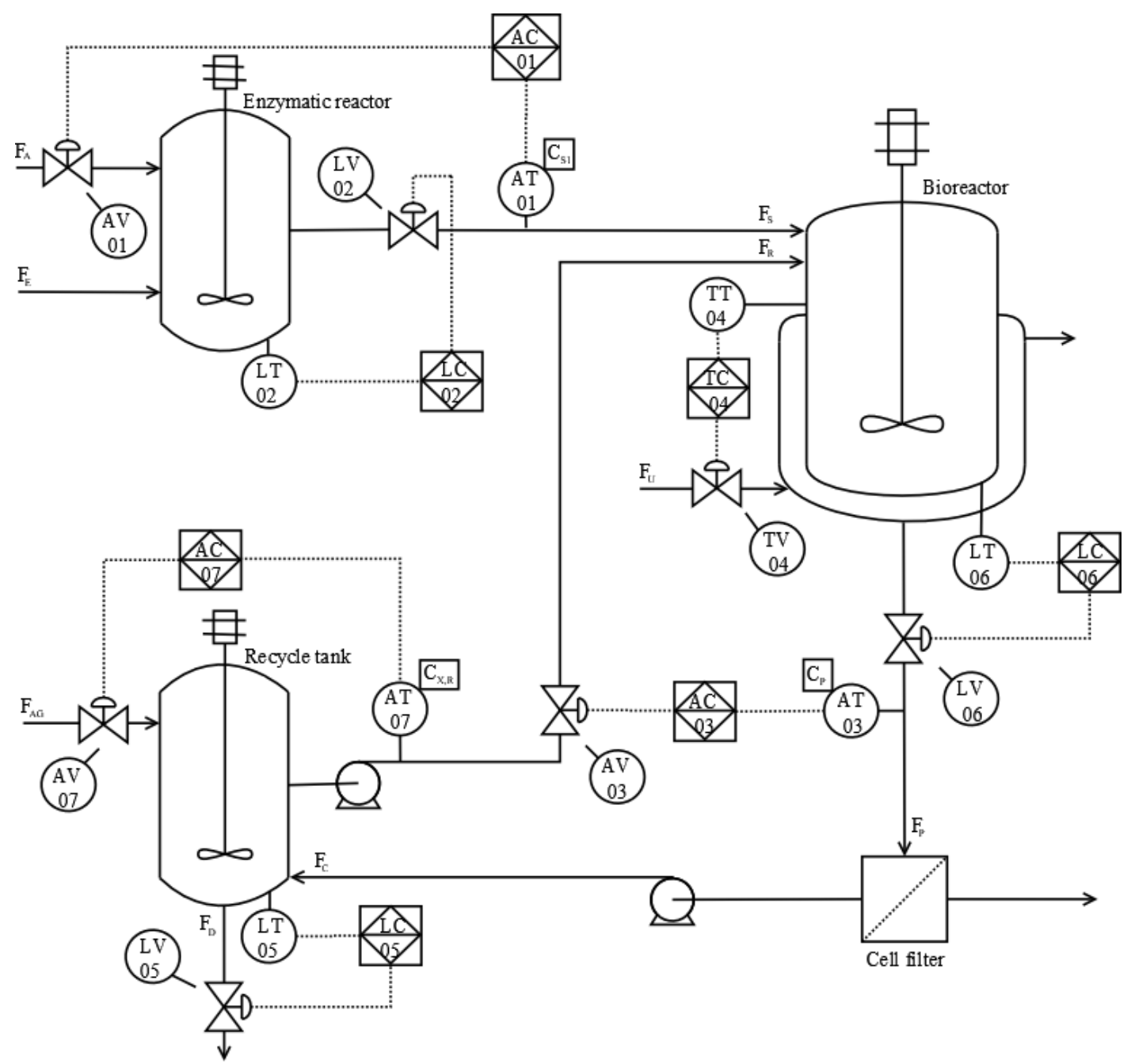

Figure 1 - PCS control system proposed to the ethanol production plant.

As mentioned before, it was evaluated one more control strategy beyond $P C S$, which is based on feedback control with PID, as commonly used in industrial plants. The second control structure, hereby called PCSF, uses the same feedback loops of PCS, however with a fuzzy logic system to reconfigure the bioreactor temperature setpoint in attempt to improve control performance in case of process disturbances. Sometimes disturbances can cause a high impact in process operation, driving it to a different operating condition and making process control defiant.

\subsection{Fuzzy logic}

A fuzzy logic system was developed to adapt the bioreactor temperature setpoint in attempt to improve plantwide control performance and it was designed to consider the influence of some disturbances variables on selected process variables, as $T_{R}$ and $C_{P}$. This strategy was set to modulate the bioreactor temperature setpoint using the rules established in the fuzzy system, which were designed from the specialist knowledge acquired about the process dynamic behavior in relation to the disturbances. In order to evaluate $P C S$ and PCSF control structures proposed in this work, a set of disturbances on $\mathrm{C}_{\mathrm{A}, \mathrm{i}}, \mathrm{C}_{\mathrm{E}, \mathrm{i}}$ and $\mathrm{T}_{\mathrm{U}, \mathrm{i}}$ was applied to establish its effects on process control and determine the most relevant disturbance variable.

\subsection{Disturbances analysis}

To analyze the disturbance effects on the plantwide control, the ethanol process with $P C S$ control structure was set initially in steady state conditions. Then, disturbances about $+/-5 \%$ for $\mathrm{C}_{\mathrm{A}, \mathrm{i}}$ 
and $\mathrm{C}_{\mathrm{E}, \mathrm{i}}$ and about $-5 \%$ to $-10 \%$ for $\mathrm{T}_{\mathrm{U}, \mathrm{i}}$ were performed considering a simulation time period of $500[\mathrm{~h}]$. Different simulations were carried out combining a set of disturbances to evaluate its effects on the process control, and control performance criteria were calculated to support this analysis.

\subsection{Control performance evaluation}

To analyze disturbance influence on process control, the performance criterion integral of absolute error $\left(\mathrm{IAE}_{\mathrm{j}}\right)$, as indicated in Equation 1, was calculated at each simulation. The higher $\mathrm{IAE}_{\mathrm{j}}$ value, greater is the error undertaken in the controlled variable in relation to its setpoint and worse control performance can be observed (Seborg et al. 2004).

$I A E_{j}=\int|e(t)| d t$

In addition to $\mathrm{IAE}_{\mathrm{j}}$, the performance criterion control effort $\left(\mathrm{CE}_{\mathrm{j}}\right)$ and the product mass production $\left(\mathrm{M}_{\mathrm{P}}\right)$, as detailed in Equations 2 and 3, respectively, were used in this paper in order to access the process control operation and performance. $\mathrm{CE}_{\mathrm{j}}$ is a criterion used for actuator effort evaluation and indicates how much the actuator was required by the control system. On the other hand, $M_{P}$ indicates the ethanol production, establishing the total mass of ethanol obtained during the process simulation.

$C E_{j}=\int|\Delta u| d t$
$M_{P}=\int\left(F_{P} \cdot C_{P}\right) d t$

\subsection{Plantwide control analysis}

The proposed plantwide control structures $P C S$ and $P C S F$ were evaluated in simulations with the same time period of $500[\mathrm{~h}]$ and considering the same and most relevant disturbances determined previously. The performance criteria $\mathrm{IAE}_{\mathrm{j}}, \mathrm{CE}_{\mathrm{j}}$ and $\mathrm{M}_{\mathrm{P}}$ were calculated for each simulation, and also process variables dynamics were analyzed to confirm the advantage of using a fuzzy system in plantwide control.

\section{Results and Discussion}

\subsection{Disturbances effects analysis}

The disturbance percentages applied to the starch concentration $\left(\mathrm{C}_{\mathrm{A}, \mathrm{i}}\right)$, enzyme concentration $\left(\mathrm{C}_{\mathrm{E}, \mathrm{i}}\right)$ and the utility temperature $\left(\mathrm{T}_{\mathrm{U}, \mathrm{i}}\right)$ inputs can be found in Table 2 . These disturbances were set to evaluate which variable have higher effect on process variables $C_{S 1}, C_{P}, C_{X, R}$ and $T_{R}$, and it was observed significant effects on IAE values, as presented in the Table 2.

From this data, it can be seen that starch concentration input has a greater influence on all process variables once considerable increase in IAE values were observed. It was expected because starch is the substrate for the enzymatic reaction, which affects the glucose production that is entirely related to the fermentation process. On the other hand, analyzing the interference of utility temperature and enzyme concentration inputs, it is possible to consider that these disturbance variables do not have much influence on the control performance of the plant. An exception is the influence of the utility temperature on the bioreactor temperature control, as expected. However, data in Table 2 indicate that, in general, even when combined steps in $\mathrm{T}_{\mathrm{U}, \mathrm{i}}$ and $\mathrm{C}_{\mathrm{E}, \mathrm{i}}$ where applied, not much deviation on process variables control was observed. 
Table 2 - IAE values for $\mathrm{C}_{\mathrm{S}}, \mathrm{C}_{\mathrm{P}}, \mathrm{C}_{\mathrm{X}, \mathrm{R}}$ and $\mathrm{T}_{\mathrm{R}}$ control loops under regulatory control.

\begin{tabular}{|c|c|c|c|c|}
\hline Disturbances & $\begin{array}{c}I A E_{C s 1} \\
{\left[\mathrm{~kg} \cdot \mathrm{h} / \mathrm{m}^{3}\right]}\end{array}$ & $\begin{array}{c}I A E_{C p} \\
{\left[\mathrm{~kg} \cdot \mathrm{h} / \mathrm{m}^{3}\right]}\end{array}$ & $\begin{array}{c}I A E_{C x, r} \\
{\left[\mathrm{~kg} \cdot \mathrm{h} / \mathrm{m}^{3}\right]}\end{array}$ & $\begin{array}{l}I A E_{T r} \\
{\left[{ }^{\circ} \mathrm{C} . \mathrm{h}\right]}\end{array}$ \\
\hline$\Delta C_{A, i}+5 \%$ & 5.17 & 22.19 & 16.57 & 63.43 \\
\hline$\Delta C_{A, i}-5 \%$ & 6.76 & 400.01 & 38.80 & 84.22 \\
\hline$\Delta T_{U, i}-5 \%$ & 0 & 1.83 & 0.91 & 11.66 \\
\hline$\Delta T_{U, i}-10 \%$ & 0 & 3.04 & 1.51 & 22.10 \\
\hline$\Delta C_{E, i}+5 \%$ & 0.09 & 0.72 & 0.48 & 1.20 \\
\hline$\Delta C_{E, i}-5 \%$ & 0.09 & 0.85 & 0.53 & 1.24 \\
\hline$\Delta C_{E, i}+5 \% ; \Delta T_{U, i}-5 \%$ & 0.09 & 2.24 & 1.37 & 12.34 \\
\hline$\Delta C_{E, i}-5 \% ; \Delta T_{U, i}-5 \%$ & 0.09 & 1.58 & 0.57 & 11.15 \\
\hline$\Delta C_{E, i}+5 \% ; \Delta T_{U, i}-10 \%$ & 0.09 & 3.44 & 1.94 & 22.39 \\
\hline$\Delta C_{E, i}-5 \% ; \Delta T_{U, i}-10 \%$ & 0.09 & 2.76 & 1.10 & 21.86 \\
\hline$\Delta C_{A, i}+5 \% ; \Delta T_{U, i}-5 \%$ & 5.17 & 21.89 & 16.84 & 63.64 \\
\hline$\Delta C_{A, i}-5 \% ; \Delta T_{U, i}-5 \%$ & 6.76 & 408.68 & 35.79 & 78.23 \\
\hline$\Delta C_{A, i}+5 \% ; \Delta T_{U, i}-10 \%$ & 5.17 & 21.84 & 17.11 & 59.84 \\
\hline$\Delta C_{A, i}-5 \% ; \Delta T_{U, i}-10 \%$ & 6.76 & 410.16 & 34.24 & 69.50 \\
\hline$\Delta C_{A, i}+5 \% ; \Delta C_{E, i}+5 \%$ & 5.22 & 22.33 & 16.71 & 64.03 \\
\hline$\Delta C_{A, i}-5 \% ; \Delta C_{E, i}+5 \%$ & 6.61 & 390.47 & 38.64 & 83.40 \\
\hline$\Delta C_{A, i}+5 \% ; \Delta C_{E, i}-5 \%$ & 5.11 & 22.05 & 16.43 & 62.82 \\
\hline$\Delta C_{A, i}-5 \% ; \Delta C_{E, i}-5 \%$ & 6.93 & 410.56 & 38.94 & 85.11 \\
\hline$\Delta C_{A, i}+5 \% ; \Delta C_{E, i}+5 \% ; \Delta T_{U, i}-5 \%$ & 5.22 & 22.02 & 16.98 & 64.16 \\
\hline$\Delta C_{A, i}-5 \% ; \Delta C_{E, i}+5 \% ; \Delta T_{U, i}-5 \%$ & 6.61 & 398.64 & 35.72 & 77.11 \\
\hline$\Delta C_{A, i}+5 \% ; \Delta C_{E, i}-5 \% ; \Delta T_{U, i}-5 \%$ & 5.11 & 21.75 & 16.70 & 63.13 \\
\hline$\Delta C_{A, i}-5 \% ; \Delta C_{E, i}-5 \% ; \Delta T_{U, i}-5 \%$ & 6.93 & 419.74 & 35.82 & 79.29 \\
\hline$\Delta C_{A, i}+5 \% ; \Delta C_{E, i}+5 \% ; \Delta T_{U, i}-10 \%$ & 5.22 & 21.97 & 17.25 & 60.28 \\
\hline$\Delta C_{A, i}-5 \% ; \Delta C_{E, i}+5 \% ; \Delta T_{U, i}-10 \%$ & 6.61 & 400.11 & 34.20 & 68.16 \\
\hline$\Delta C_{A, i}+5 \% ; \Delta C_{E, i}-5 \% ; \Delta T_{U, i}-10 \%$ & 5.11 & 21.71 & 16.97 & 59.41 \\
\hline$\Delta C_{A, i}-5 \% ; \Delta C_{E, i}-5 \% ; \Delta T_{U, i}-10 \%$ & 6.93 & 421.24 & 34.24 & 70.78 \\
\hline
\end{tabular}

Once disturbances in $\mathrm{C}_{\mathrm{A}, \mathrm{i}}$ have a greater impact over plant control performance, the IAE values in Table 1 allows to verify that decreasing $\mathrm{C}_{\mathrm{A}, \mathrm{i}}$ by $5 \%$, in comparison to increasing its initial value by the same percentage, the values of IAE increased $30.75 \%, 134.16 \%, 32.78 \%$ and $1702.66 \%$ for $\mathrm{C}_{\mathrm{S} 1}, \mathrm{C}_{\mathrm{X}, \mathrm{R}}, \mathrm{T}_{\mathrm{R}}$ and $\mathrm{C}_{\mathrm{P}}$ respectively. It can also be observed that IAE values indicated in Table 2 are differently attenuated or intensified depending on the joint influence of other disturbances. These results indicate that the ethanol process simulated under PCS plantwide control has a considerable nonlinear behavior, highlighting the necessity of a nonlinear control technique to improve control performance. The results also indicate that reducing starch concentration input has a higher effect on plantwide control than increasing it, what can be explained not only by the process nonlinear dynamics, but also because glucose concentration in bioreactor $\left(\mathrm{C}_{\mathrm{S}}\right)$ is almost entirely consumed during normal operating conditions.

Another interesting observation is the high values obtained for IAE $_{C p}$ when negative disturbances on $\mathrm{C}_{\mathrm{A}, \mathrm{i}}$ were applied. These results can be explained by the change in process operating condition, driving the manipulated variable $F_{R}$ to saturation and process variable $C_{P}$ to a new steady state value that is beyond control limits, as can be seen in Figure 2. The main impact of this phenomenon is the reduction on ethanol production rate that affects the process productivity, being a significant negative outcome. Overcome this problem becomes imperative and the use of a specialist system like fuzzy logic is required. Thus, a fuzzy system was developed for PCSF in attempt to surpass this drawback, and PCS and PCSF control performances were evaluated considering different scenarios with $\mathrm{C}_{\mathrm{A}, \mathrm{i}}$ and $\mathrm{C}_{\mathrm{E}, \mathrm{i}}$ disturbances. 

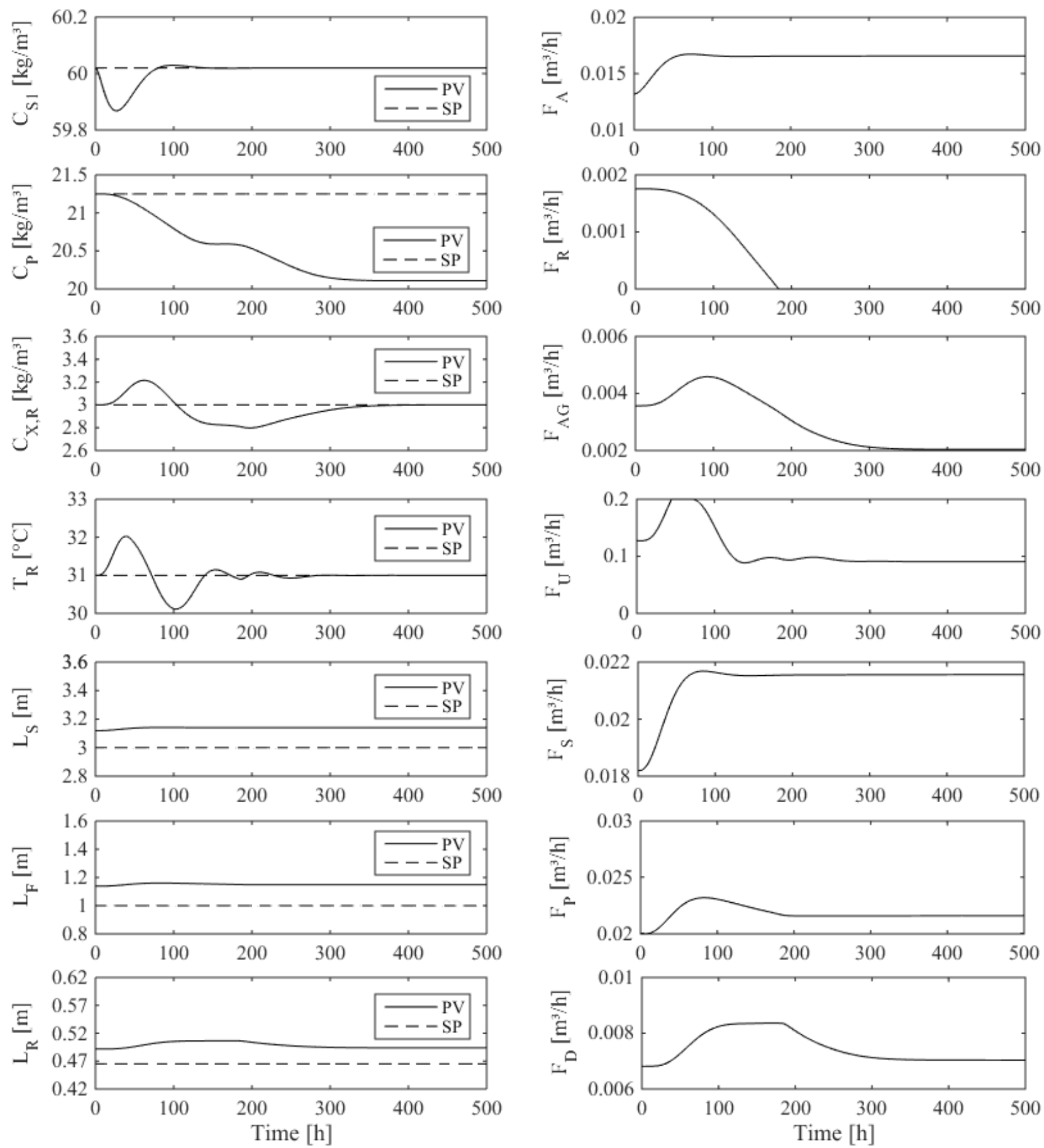

Figure 2 - Process control using PCS in case of $\Delta \mathrm{C}_{\mathrm{A}, \mathrm{i}}-\mathbf{5 \%}$.

\subsection{Fuzzy logic development}

The fuzzy system developed to adapt the setpoint profile of the bioreactor temperature aims to improve control performance, reducing performance criteria $\mathrm{IAE}_{\mathrm{j}}$ and $\mathrm{CE}_{\mathrm{j}}$ values in situations of greater deregulation on the ethanol process control. Besides the attempt to decrease these criteria values, the proposed fuzzy system also aims at least to maintain the productivity of the plant by keeping $\mathrm{C}_{\mathrm{P}}$ regulated in its setpoint, especially in the most critical moments of operation as discussed before.

The fuzzy system was developed using two input variables, the disturbances $C_{A, i}$ and $C_{E, i}$. In this way, the fuzzy system should be able to identify whether process operating condition must be adapted or not. As output variable, the bioreactor temperature setpoint was selected once the yeast metabolism during fermentation process is directly related to temperature. By specialist knowledge 
about this process, it was observed that in case of low $\mathrm{C}_{\mathrm{A}, \mathrm{i}}$ input, the bioreactor temperature should slightly increase to allow $\mathrm{C}_{\mathrm{P}}$ control. Thus, the base rule and the membership functions for each input and output variables were established using this specialist knowledge and the response surface is shown in Figure 3. As can be seen, the fuzzy system allows bioreactor temperature setpoint increasing when low $\mathrm{C}_{\mathrm{A}, \mathrm{i}}$ input is observed.

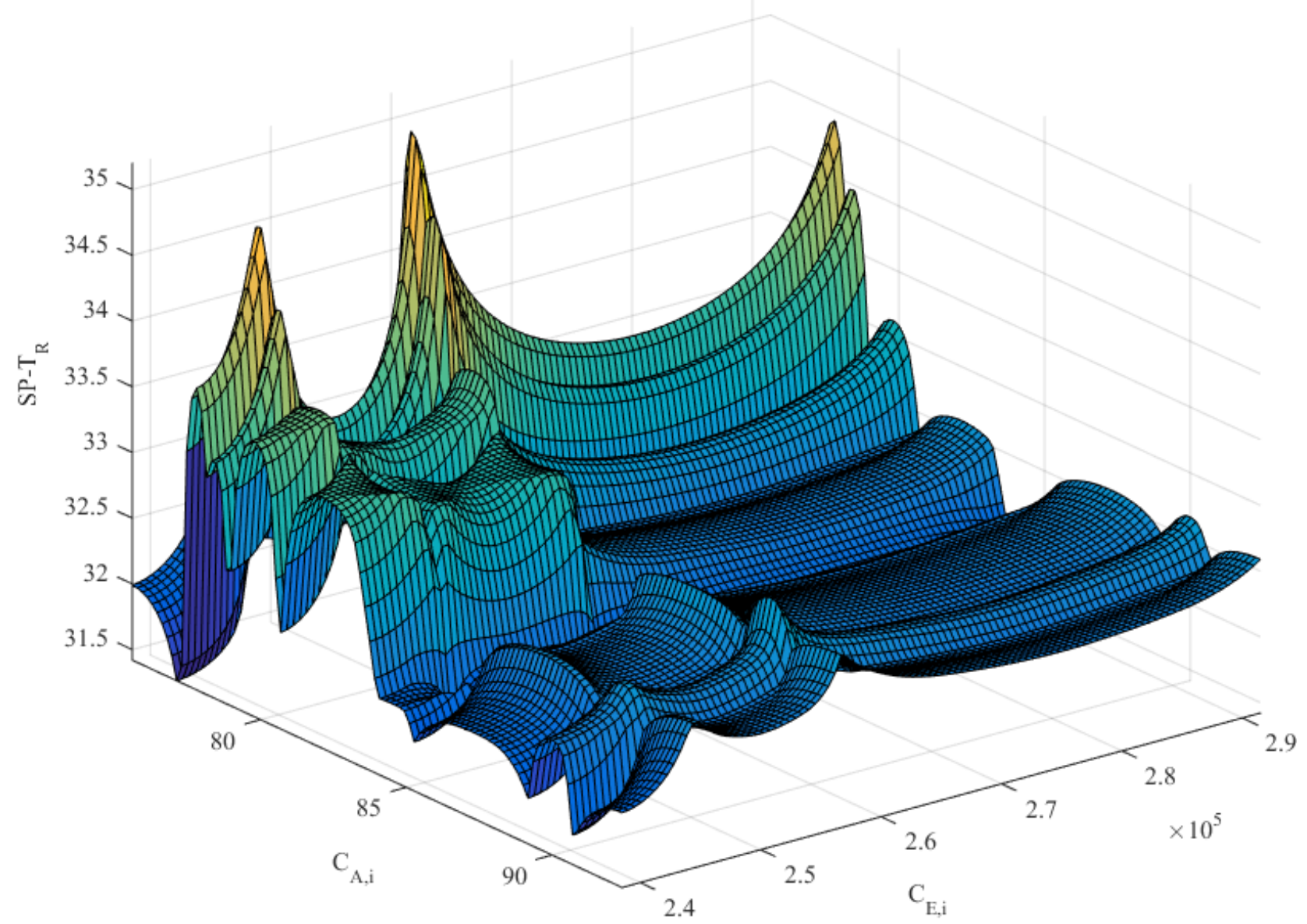

Figure 3 - Control surface of the fuzzy system utilized in PCSF .

\subsection{Regulatory control analysis}

As mentioned before, disturbances on $\mathrm{C}_{\mathrm{A}, \mathrm{i}}$ and $\mathrm{C}_{\mathrm{E}, \mathrm{i}}$ were considered during simulations to evaluate the control performance of both $P C S$ and $P C S F$ control structures proposed in this paper. At all, four different simulations were carried out considering disturbances about $+/-5 \%$ from the steady state value for both $\mathrm{C}_{\mathrm{A}, \mathrm{i}}$ and $\mathrm{C}_{\mathrm{E}, \mathrm{i}}$ variables. The performance criteria IAE, $\mathrm{CE}$ and ethanol mass production $M_{P}$ were calculated for each simulation and the results are presented in Tables 3, 4 and 5, respectively.

Based on data presented in Tables 3 and 4, no difference was observed in terms of control performance for $\mathrm{C}_{\mathrm{S} 1}$ between $P C S$ and $P C S F$ control structures. It is explained because the control improvement proposed on $P C S F$ does not affect the enzymatic reactor operating conditions, once the recycle stream is added at downstream and the fuzzy system is set to adapt only the bioreactor temperature setpoint. Therefore, in order to compare PCS and PCSF control performance, $\mathrm{C}_{\mathrm{S} 1}$ control loop is not further considered.

In terms of $C_{P}$ control, the results in Table 3 indicates that PCSF allowed a considerable improvement on process variable regulation by decreasing $\mathrm{IAE}_{\mathrm{Cp}}$ values when considering the worse scenario of disturbances with negative steps on $\mathrm{C}_{\mathrm{A}, \mathrm{i}}$. This observation is corroborated by the analysis of $\mathrm{C}_{\mathrm{P}}$ dynamic responses under PCS and PCSF control, presented in Figure 3. 
Table 3 - IAE values for $\mathrm{C}_{\mathrm{S}}, \mathrm{C}_{\mathrm{P}}, \mathrm{C}_{\mathrm{X}, \mathrm{R}}$ and $\mathrm{T}_{\mathrm{R}}$ control loops under regulatory control.

\begin{tabular}{|c|c|c|c|c|c|c|c|}
\hline \multicolumn{2}{|c|}{ Disturbances: } & \multicolumn{2}{|c|}{$\begin{array}{ll}\Delta \mathrm{C}_{\mathrm{A}, \mathrm{i}} & \mathbf{- 5 \%} \\
\Delta \mathrm{C}_{\mathrm{E}, \mathrm{i}} & \mathbf{- 5 \%}\end{array}$} & \multicolumn{2}{|c|}{ Disturbances: } & \multicolumn{2}{|c|}{$\begin{array}{cc}\Delta \mathrm{C}_{\mathrm{A}, \mathrm{i}} & \mathbf{- 5 \%} \\
\Delta \mathrm{C}_{\mathrm{E}, \mathrm{i}} & \mathbf{+ 5 \%}\end{array}$} \\
\hline & $P C S$ & $P C S F$ & Difference & & $P C S$ & $P C S F$ & Difference \\
\hline$I A E_{C s I}$ & 6.93 & 6.93 & $0.0 \%$ & $I A E_{C s I}$ & 6.61 & 6.61 & $0.0 \%$ \\
\hline$I A E_{C p}$ & 410.56 & 19.81 & $-95.17 \%$ & $I A E_{C p}$ & 390.47 & 62.75 & $-83.93 \%$ \\
\hline$I A E_{C x, r}$ & 38.94 & 30.91 & $-20.62 \%$ & $I A E_{C x, r}$ & 38.64 & 37.56 & $-2.80 \%$ \\
\hline$I A E_{T r}$ & 85.11 & 109.13 & $+28.22 \%$ & $I A E_{T r}$ & 83.40 & 100.83 & $+20.90 \%$ \\
\hline \multicolumn{2}{|c|}{ Disturbances: } & \multicolumn{2}{|c|}{$\begin{array}{ll}\Delta \mathrm{C}_{\mathrm{A}, \mathrm{i}} & \mathbf{+ 5 \%} \\
\Delta \mathrm{C}_{\mathrm{E}, \mathrm{i}} & \mathbf{- 5 \%}\end{array}$} & \multicolumn{2}{|c|}{ Disturbances: } & $\begin{array}{l}\Delta \mathbf{C}_{\mathrm{A}, \mathrm{i}} \\
\Delta \mathbf{C}_{\mathrm{E}, \mathrm{i}}\end{array}$ & $\begin{array}{l}+5 \% \\
+5 \% \\
\end{array}$ \\
\hline & $P C S$ & $P C S F$ & Difference & & $P C S$ & $P C S F$ & Difference \\
\hline$I A E_{C s I}$ & 5.11 & 5.11 & $0.0 \%$ & $I A E_{C s 1}$ & 5.22 & 5.22 & $0.0 \%$ \\
\hline$I A E_{C p}$ & 22.05 & 32.79 & $+48.71 \%$ & $I A E_{C p}$ & 22.33 & 32.80 & $+46.89 \%$ \\
\hline$I A E_{C x, r}$ & 16.43 & 18.52 & $+12.72 \%$ & $I A E_{C x, r}$ & 16.71 & 18.69 & $+11.85 \%$ \\
\hline$I A E_{T r}$ & 62.82 & 57.02 & $-9.23 \%$ & $I A E_{T r}$ & 64.03 & 57.79 & $-9.75 \%$ \\
\hline
\end{tabular}

As previously observed, $P C S$ was unable to control $C_{P}$ because bioreactor temperature setpoint was kept constant and equal to $31^{\circ} \mathrm{C}$, driving $\mathrm{C}_{\mathrm{P}}$ to a new steady state value beyond the control limits. In contrast, $P C S F$ allowed $\mathrm{C}_{\mathrm{P}}$ control by changing the bioreactor temperature setpoint from $31^{\circ} \mathrm{C}$ to almost $33.2^{\circ} \mathrm{C}$. This slight change in bioreactor temperature operating condition improved not only $\mathrm{C}_{\mathrm{P}}$ control by reducing $\mathrm{IAE}_{\mathrm{Cp}}$, but also decreased $\mathrm{CE}_{\mathrm{Cp}}$ and increased $\mathrm{M}_{\mathrm{P}}$, indicating that $P C S F$ allowed a more productive plant operation.
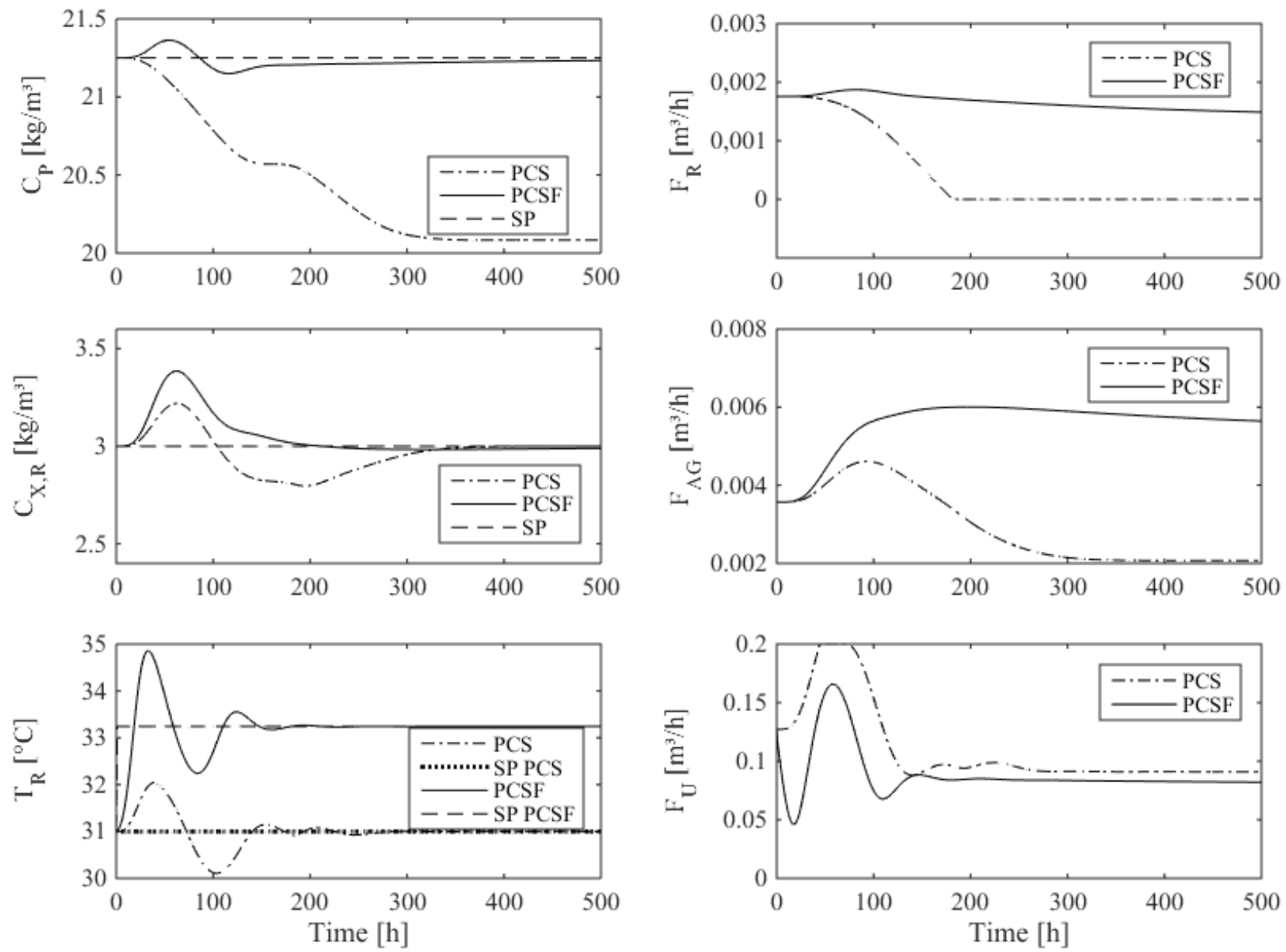

Figure 3 - Process control in case of both $\Delta \mathrm{C}_{\mathrm{A}, \mathrm{i}}$ and $\Delta \mathrm{C}_{\mathrm{E}, \mathrm{i}}$ equals to $-5 \%$. 
Table 4 - $\mathbf{C E}$ values for $\mathrm{C}_{\mathrm{S}}, \mathrm{C}_{\mathrm{P}}, \mathrm{C}_{\mathrm{X}, \mathrm{R}}$ and $\mathrm{T}_{\mathrm{R}}$ control loops under regulatory control.

\begin{tabular}{|c|c|c|c|c|c|c|c|}
\hline \multicolumn{2}{|c|}{ Disturbances: } & $\begin{array}{l}\Delta \mathrm{C}_{\mathrm{A}, \mathrm{i}} \\
\Delta \mathrm{C}_{\mathrm{E}, \mathrm{i}}\end{array}$ & $\begin{array}{l}-5 \% \\
-5 \%\end{array}$ & \multicolumn{2}{|c|}{ Disturbances: } & \multicolumn{2}{|c|}{$\begin{array}{ll}\Delta \mathrm{C}_{\mathrm{A}, \mathrm{i}} & -\mathbf{5 \%} \\
\Delta \mathrm{C}_{\mathrm{E}, \mathrm{i}} & +\mathbf{5 \%} \\
\end{array}$} \\
\hline & $P C S$ & $P C S F$ & Difference & & $P C S$ & $P C S F$ & Difference \\
\hline$C E_{C s 1}$ & 6.30 & 6.30 & $0.0 \%$ & $C E_{C s 1}$ & 6.01 & 6.01 & $0.0 \%$ \\
\hline$C E_{C p}$ & 52.67 & 14.96 & $-71.60 \%$ & $C E_{C p}$ & 52.69 & 47.60 & $-9.66 \%$ \\
\hline$C E_{C x, r}$ & 17.92 & 13.98 & $-21.99 \%$ & $C E_{C x, r}$ & 17.77 & 17.25 & $-2.93 \%$ \\
\hline$C E_{T r}$ & 157.63 & 247.49 & $+57.01 \%$ & $C E_{T r}$ & 158.77 & 228.29 & $+43.79 \%$ \\
\hline \multicolumn{2}{|c|}{ Disturbances: } & $\begin{array}{l}\Delta \mathbf{C}_{\mathrm{A}, \mathrm{i}} \\
\Delta \mathbf{C}_{\mathrm{E}, \mathrm{i}}\end{array}$ & $\begin{array}{r}+5 \% \\
-5 \%\end{array}$ & \multicolumn{2}{|c|}{ Disturbances: } & $\begin{array}{l}\Delta \mathbf{C}_{\mathrm{A}, \mathrm{i}} \\
\Delta \mathbf{C}_{\mathrm{E}, \mathrm{i}}\end{array}$ & $\begin{array}{l}+5 \% \\
+5 \%\end{array}$ \\
\hline & $P C S$ & PCSF & Difference & & $P C S$ & $P C S F$ & Difference \\
\hline$C E_{C s 1}$ & 4.76 & 4.76 & $0.0 \%$ & $C E_{C s 1}$ & 4.86 & 4.86 & $0.0 \%$ \\
\hline$C E_{C p}$ & 16.57 & 24.64 & $+48.70 \%$ & $C E_{C p}$ & 16.78 & 24.65 & $+46.90 \%$ \\
\hline$C E_{C x, r}$ & 7.72 & 8.60 & $+11.40 \%$ & $C E_{C x, r}$ & 7.85 & 8.69 & $+10.70 \%$ \\
\hline$C E_{T r}$ & 141.47 & 129.30 & $-8.60 \%$ & $C E_{T r}$ & 144.19 & 131.03 & $-9.13 \%$ \\
\hline
\end{tabular}

Although these advantages, it could be observed that $T_{R}$ control was negatively affected, by the increasement of $\mathrm{IAE}_{\operatorname{Tr}}$ and $\mathrm{CE}_{\mathrm{Tr}}$ when using PCSF. However, the use of PCSF control allowed the manipulated variables $\mathrm{F}_{\mathrm{R}}$ and $\mathrm{F}_{\mathrm{U}}$ to do not reach their saturation limits, as occurred with $P C S$ during simulation. This is a desirable behavior to manipulated variables in any control loop once enhances process controllability. Thus, the improvements obtained utilizing the fuzzy system, especially on $\mathrm{C}_{\mathrm{P}}$ control, surpass the identified drawbacks and justify its application in plantwide control.

Meanwhile, both criteria $\mathrm{IAE}_{\mathrm{Cx}, \mathrm{r}}$ and $\mathrm{CE}_{\mathrm{Cx}, \mathrm{r}}$ were improved in case of negative disturbance in $\mathrm{C}_{\mathrm{A}, \mathrm{i}}$, allowing better performance for $\mathrm{C}_{\mathrm{X}, \mathrm{R}}$ control loop. This result demonstrates that, even in case of input disturbances on $\mathrm{C}_{\mathrm{A}, \mathrm{i}}$ and $\mathrm{C}_{\mathrm{E}, \mathrm{i}}$, the recycle tank was able to support fermentation process supplying the required biomass with the recycle stream.

Table 5 - MP values obtained under regulatory control.

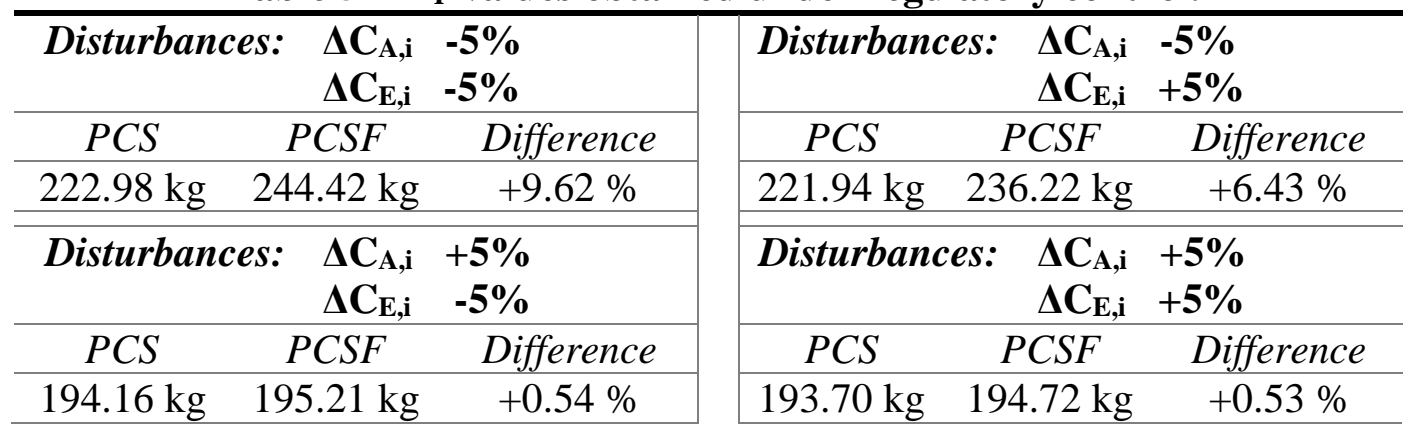

On the other hand, considering both simulations with positive disturbance on $\mathrm{C}_{\mathrm{A}, \mathrm{i}}$, the results indicate a deterioration on control indexes $\mathrm{IAE}_{\mathrm{Cp}}, \mathrm{IAE}_{\mathrm{Cx}, \mathrm{r}}, \mathrm{CE}_{\mathrm{Cp}}$ and $\mathrm{CE}_{\mathrm{Cx}, \mathrm{r}}$, consequence of high overshoot and response time when using PCSF against $P C S$, as can be seen in Figure 4. Although these facts, no saturation was observed on manipulated variables when applying both $P C S$ and $P C S F$ structures. Notwithstanding, good control performance was obtained for $\mathrm{T}_{\mathrm{R}}$, with $\mathrm{IAE}_{\mathrm{Tr}}$ and $\mathrm{CE}_{\mathrm{Tr}}$ values decreasing, combined to a slight increase in $\mathrm{M}_{\mathrm{P}}$. It indicates that even PCSF presenting worse control performance compared to $P C S$ for positive disturbance on $\mathrm{C}_{\mathrm{A}, \mathrm{i}}$, the ethanol mass production was positively affected, raising process productivity.

Thus, these results corroborate the analysis that indicates the advantage of using a specialist system like fuzzy logic to improve plantwide control performance, in this case applied to an ethanol production plant. 

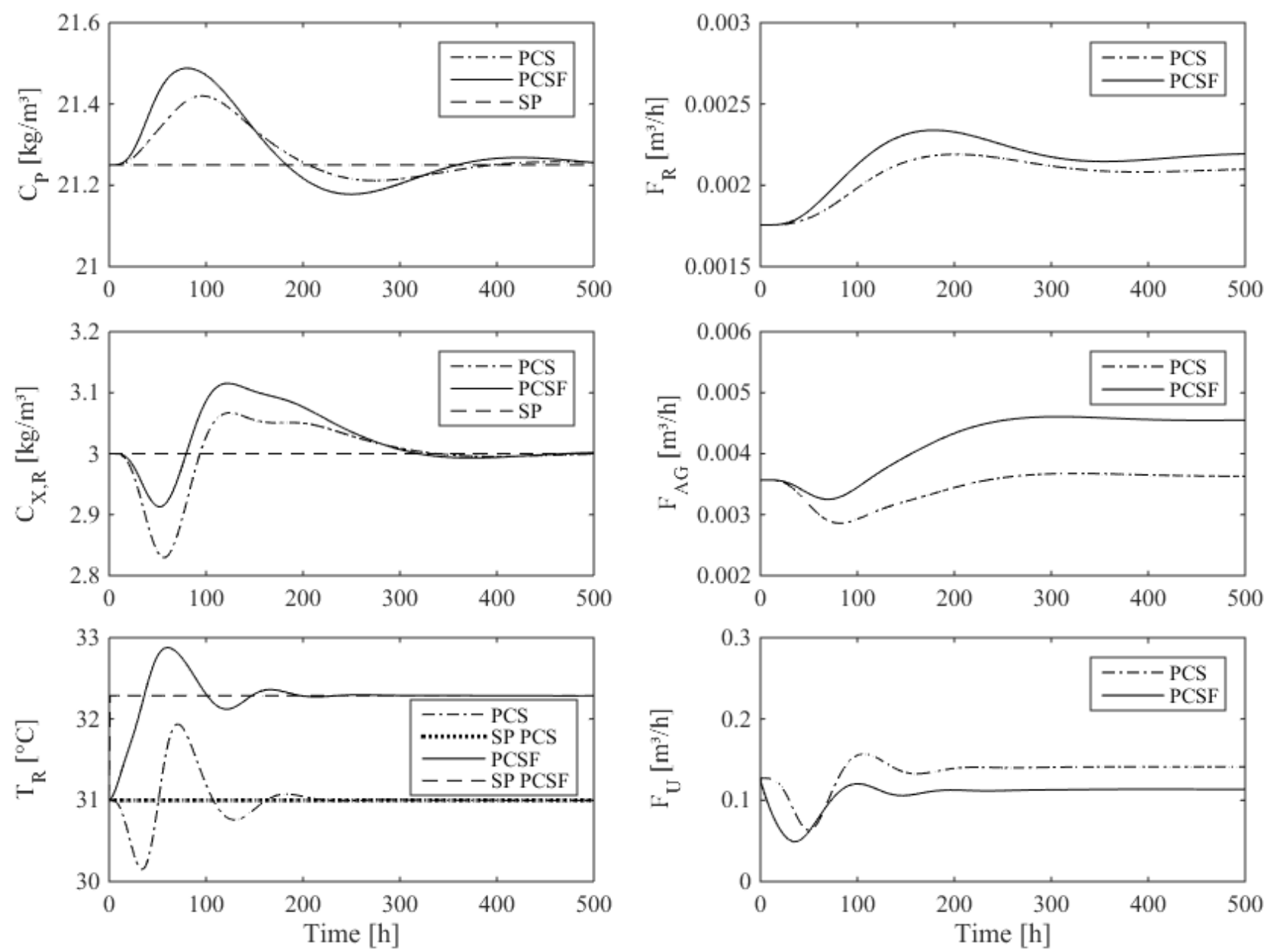

Figure 4 - Process control in case of both $\Delta C_{A, i}$ and $\Delta C_{E, i}$ equals to $+5 \%$.

\section{Conclusion}

In view of the results obtained in this work, it was found that the application of a specialist system like fuzzy logic in plantwide control enables process control performance enhancement like IAE and CE criteria values decreasement. In this paper, a fuzzy system was developed to adapt the bioreactor temperature setpoint in a plantwide control structure in cases of ethanol production plant deregulation.

Initially, simulations were carried out to identify the relevant disturbances on control loops and it was observed that starch concentration input $\left(\mathrm{C}_{\mathrm{A}, \mathrm{i}}\right)$ showed the most relevant influence on plantwide process control. The impact was observed mostly in cases of $\mathrm{C}_{\mathrm{A}, \mathrm{i}}$ reduction, driving product concentration output $\left(\mathrm{C}_{\mathrm{P}}\right)$ to a different value in steady state condition and, as a consequence, decreasing process productivity.

Then, a plantwide control structure using a fuzzy logic system to adapt the bioreactor temperature setpoint was proposed and evaluated considering the disturbances $\mathrm{C}_{\mathrm{A}, \mathrm{i}}$ and enzyme concentration input $\left(\mathrm{C}_{\mathrm{E}, \mathrm{i}}\right)$. In general, the results indicated better process control performance with the applied disturbances, resulting in IAE and CE criteria decreasement and ethanol mass production increasement, in comparison to a plantwide process control structure without a specialist system.

Thus, by the satisfactory results observed with the use of a fuzzy logic system developed to avoid $C_{P}$ deregulation and to improve process control performance in the simulated ethanol process plant, it can be concluded that, in general, plantwide control can be enhanced with the application of specialist systems like fuzzy logic.

\section{Acknowledgments}


The authors appreciate the financial support from FAPITEC - Fundação de Apoio à Pesquisa e à Inovação Tecnológica do Estado de Sergipe under FAPITEC/SE/FUNTEC/CAPES No 04/2019 research project.

\section{References}

BABUSKA, R., OOSTERHOFF, J., OUDSHOORN, A., BRUIJN, P. M. (2002) Fuzzy self-tuning PI control of $\mathrm{pH}$ in fermentation. Engineering Applications of Artificial Intelligence, v. 15, p. $3-15$.

BATISTA, R. G.; MENEGHETTI, C. R. Sistema comparativo de controle inteligente de nível aplicado às lógicas Fuzzy e PID. Revista Ciências e Tecnologia, Campinas, v.21, n. 38, p. 5363, jan./jun. 2018 - ISSN: 2236-6733.

CASTILLO, O., MELIN, P. (2021) A new fuzzy fractal control approach of non-linear dynamics systems: The case of controlling the COVID-19 pandemics. Chaos, Solitons and Fractals, v. 151, p. 111250, doi: https://doi.org/10.1016/j.chaos.2021.111250

CHAI, T., QIN, S. J., WANG, H. (2014) Optimal operational control for complex industrial processes. Annual Reviews in Control, v. 38, 81 - 92, doi: http://dx.doi.org/10.1016/j.arcontrol.2014.03.005

DA SILVA, B. F., SCHMITZ, J. E., FRANCO, I. C., DA SILVA, F. V. (2021) Plantwide control systems design and evaluation applied to biodiesel production. Biofuels, v. 12:10, p. 11991207, doi: https://doi.org/10.1080/17597269.2019.1600456

DOWNS, J. J., VOGEL, E. F. (1993) A Plant-wide industrial process control problem. Computers Chemical Engineering, v. 17, 245 - 255.

FONSECA, R. R., DANTAS, T. S. S., DA SILVA, F. V., Simulation and control of enzymatic hydrolysis reactor of soluble potato starch by Aspergillus niger glucoamylase for fermentation process feed, Anais do XX Congresso Brasileiro de Engenharia Química, Florianópolis, 2014.

FONSECA, R. R., SENCIO, R. R., FRANCO, I. C., DA SILVA, F. V. (2018) An Adaptive Fuzzy Feedforward-Feedback Control System Applied to a Saccharification Process. Chemical Product and Process Modeling, v. 13, n. 4, p. 20180014, doi: https://doi.org/10.1515/cppm2018-0014

HUO, J., CHAN, F. T. S., LEE, C. K. M., STRANDHAGEN, J. O., NIU, B. (2020) Smart control of the assembly process with a fuzzy control system in the context of industry 4.0. Advanced Engineering Informatics, v. 43, p. 101031, doi: https://doi.org/10.1016/j.aei.2019.101031

JAHANSHAHI, E., KRISHNAMOORTHY, D., CODAS, A.,FOSS, B., SKOGESTAD, S. (2020) Plantwide control of an oil production network. Computers and Chemical Engineering, v. 136, p. 106765, doi: https://doi.org/10.1016/j.compchemeng.2020.106765

JASPER, M. Fontes de Biomassa e Potenciais de Uso. Editora Atena, 2019.

LIN, Y., TANAKA, S. (2006) Ethanol fermentation from biomass resources: current state and prospects. Applied Microbiology and Biotechnoly, v. 69, 627 - 642, doi: https://doi.org/10.1007/s00253-005-0229-x

LUYBEN, W. (2019) Simplified plantwide control structure for the diethyl oxalate process. Computers and Chemical Engineering, v. 126, p. $451-464$, doi: https://doi.org/10.1016/j.compchemeng.2019.04.027

LUYBEN, W. L., TYRÉUS, B. D., LUYBEN, M. L. Plantwide Process Control. $1^{\text {st }}$ ed., New York, McGraw-Hill, 1998.

MATHEUS, L. Sintonia de um Controlador PID para Sistema de Aquecimento em Batelada de um Mini-tanque de uma Microcervejaria. Universidade do Sul de Santa Catarina, Tubarão, 2019.

NAGY, Z. K. (2007) Model based control of a yeast fermentation bioreactor using optimally designed artificial neural networks. Chem. Eng. J., v. 127, p. 95 - 109. 
OCHOA, S., REPKE, J.-U., WOZNY, G. (2010b) Integrating real-time optimization and control for optimal operation: Application to the bio-ethanol process. Biochemical Engineering Journal, v. 53, 18 - 25, doi:https://doi.org/10.1016/j.bej.2009.01.005

OCHOA, S., WOZNY, G., REPKE, J.-U. (2010a) Plantwide Optimizing Control of a continuous bioethanol production process. Journal of Process Control, v. 20, 983 - 998, doi:https://doi.org/10.1016/j.jprocont.2010.06.010

OLIVEIRA, L.; SERRA, J. C.; MAGALHÃES, K. Estudo Comparativo das Diferentes Tecnologias Utilizadas para Produção de Etanol. Universidade Federal de Goiás, Revista eletrônica do curso de geografia, Jataí, 2012.

POLAKOVIC, M., BRYJAC, J. (2004) Modelling of potato starch saccharification by an Aspergillus niger glucoamylase. Biochemical Engineering Journal, v. 18, 57 - 63, doi: https://doi.org/10.1016/S1369-703X(03)00164-5

PRECUP, R.-E., HELLENDOORN, H. (2011) A survey on industrial applications of fuzzy control. Computers in Industry, v. 62, 213 - 225, doi: https://10.1016/j.compind.2010.10.001

RIAZ, M., RASHI, M. H., SAWYER, L., AKHTAR, S., JAVED, M. R., NADEEM, H., WEAR, M. (2012) Physiochemical properties and kinetics of glucoamylase produced from deoxy-Dglucose resistant mutant of Aspergillus niger for soluble starch hydrolysis. Food Chemistry, v. 130, 24 - 30, doi: https://doi.org/10.1016/j.foodchem.2011.06.037

SEBORG, D. E., EDGAR, T. F., MELLICHAMP, D. A. Process Dynamics and Control. $2^{\text {nd }}$ ed., Hoboken, John Wiley \& Sons, 2004.

WAEWSAK, C., NOPHARATANA, A., CHAIPRASERT, P. (2010) Neural-fuzzy control system application for monitoring process response and control of anaerobic hybrid reactor in wastewater treatment and biogas production. Journal of Environmental Sciences, v. 22(12), p. 1883 - 1890, doi: https://10.1016/S1001-0742(09)60334-X 


\section{Appendix}

The Equations 1 to 5 are adapted from Fonseca et al. (2014) and represent the mathematical model of the enzymatic reactor.

$$
\begin{aligned}
& A_{S} \frac{d L_{S(t)}}{d t}=F_{A(t)}+F_{E(t)}-F_{S(t)} \\
& \frac{d C_{A(t)}}{d t}=\frac{F_{A(t)} C_{A, i(t)}-F_{S(t)} C_{A(t)}-1,11 k_{1(t)} C_{A(t)} A_{S} L_{S(t)}}{A_{S} L_{S(t)}} \\
& \frac{d C_{S 1(t)}}{d t}=\frac{1,11 k_{1} C_{A(t)} A_{S} L_{S(t)}-F_{S(t)} C_{S 1(t)}}{A_{S} L_{S(t)}} \\
& \frac{d C_{E(t)}}{d t}=\frac{F_{E(t)} C_{E, i(0)}-F_{S(t)} C_{E(t)}}{A_{S} L_{S(t)}} \\
& k_{1(t)}=\frac{k C_{E(t)}}{k_{m}\left(1+C_{S 1(t)} / k_{g}\right)+C_{A(t)}\left(1+C_{A(t)} / k_{S}\right)}
\end{aligned}
$$

The Equations 6 to 20 are adapted from Nagy (2007) and represent the mathematical model of the bioreactor.

$$
\begin{aligned}
& A_{F} \frac{d L_{F(t)}}{d t}=F_{S(t)}+F_{R(t)}-F_{P(t)} \\
& \frac{d C_{X(t)}}{d t}=\frac{F_{R(t)}}{A_{F} L_{F(t)}} C_{X, R(t)}+\mu_{X} C_{X(t)} \frac{C_{S}(t) e^{\left(-K_{P} \cdot C_{P(t)}\right)}}{K_{S}+C_{S(t)}}-\frac{F_{P(t)}}{A_{F} L_{F(t)}} C_{X(t)} \\
& \frac{d C_{P(t)}}{d t}=\mu_{P} C_{X(t)} \frac{C_{S(t)} e^{\left(-K_{P 1} \cdot C_{P(t)}\right)}}{K_{S 1}+C_{S(t)}}-\frac{F_{P(t)}}{A_{F} L_{F(t)}} C_{P(t)} \\
& \frac{d C_{S(t)}}{d t}=-\frac{1}{R_{S X}} \mu_{X} C_{X(t)} \frac{C_{S(t)} e^{\left(-K_{P} \cdot C_{P(t)}\right)}}{K_{S}+C_{S(t)}}-\frac{1}{R_{S P}} \mu_{P} C_{X(t)} \frac{C_{S(t)} e^{\left(-K_{P 1} \cdot C_{P(t)}\right)}}{K_{S 1}+C_{S(t)}}+\frac{F_{S(t)}}{A_{F} L_{F(t)}} C_{S 1(t)} \\
& -\frac{F_{P(t)}}{A_{F} L_{F(t)}} C_{S(t)}+\frac{1,11 k_{1 F(t)} C_{A F(t)} A_{F} L_{F(t)}}{A_{F} L_{F(t)}} \\
& \frac{d C_{A, F(t)}}{d t}=\frac{F_{S(t)} C_{A(t)}-F_{P(t)} C_{A, F(t)}-1,11 k_{1, F(t)} C_{A, F(t)} A_{F} L_{F(t)}}{A_{F} L_{F(t)}} \\
& \frac{d C_{E, F(t)}}{d t}=\frac{F_{S(t)} C_{E(t)}-F_{P(t)} C_{E, F(t)}}{A_{F} L_{F(t)}} \\
& \frac{d C_{O_{2}(t)}}{d t}=K_{L} a\left(C_{O_{2}}^{*}-C_{O_{2}(t)}\right)-r_{O_{2}(t)}-\frac{F_{P(t)}}{A_{F} L_{F(t)}} C_{O_{2}(t)}
\end{aligned}
$$




$$
\begin{aligned}
& \frac{d T_{r(t)}}{d t}=\frac{F_{S(t)}}{A_{F} L_{F(t)}}\left(T_{S}+273\right)+\frac{F_{R(t)}}{A_{F} L_{F(t)}}\left(T_{R}+273\right)-\frac{F_{P(t)}}{A_{F} L_{F(t)}}\left(T_{r}+273\right)+\frac{r_{O_{2}(t)} \Delta H_{r}}{32 \rho_{r} C_{\text {heat }, r}} \\
& -\frac{K_{T} A_{F, j}\left(T_{r(t)}-T_{U(t)}\right)}{A_{F} L_{F(t)} \rho_{r} C_{h e a t, r}} \\
& \frac{d T_{U(t)}}{d t}=\frac{F_{U(t)}}{V_{j}}\left(T_{U i}-T_{U(t)}\right)+\frac{K_{T} A_{F, j}\left(T_{r(t)}-T_{U(t)}\right)}{V_{j} \rho_{U} C_{\text {heat }, U}} \\
& k_{1 F(t)}=\frac{k C_{E, F(t)}}{k_{m}\left(1+C_{S(t)} / k_{g}\right)+C_{A, F(t)}\left(1+C_{A, F(t)} / k_{S}\right)} \\
& C_{O_{2}}^{*}=\left(14.16-0.3943 T_{r(t)}+0.007714 T_{r(t)}^{2}-0.0000646 T_{r(t)}^{3}\right) 10^{-\sum H_{i} I_{i}} \\
& \sum H_{i} I_{i}=0.5 H_{\mathrm{Na}} \frac{m_{\mathrm{NaCl}}}{M_{\mathrm{NaCl}}} \frac{M_{\mathrm{Na}}}{V}+2 H_{\mathrm{Ca}} \frac{m_{\mathrm{CaCO}_{3}}}{M_{\mathrm{CaCO}_{3}}} \frac{M_{\mathrm{Ca}}}{V}+2 H_{\mathrm{Mg}} \frac{m_{\mathrm{MgCl}_{2}}}{M_{\mathrm{MgCl}_{2}}} \frac{M_{M g}}{V} \\
& +0.5 H_{\mathrm{Cl}}\left(\frac{m_{\mathrm{NaCl}}}{M_{\mathrm{NaCl}}}+2 \frac{m_{\mathrm{MgCl}_{2}}}{M_{\mathrm{MgCl}_{2}}}\right) \frac{M_{\mathrm{Cl}}}{V}+2 H_{\mathrm{CO}_{3}} \frac{m_{\mathrm{CaCO}_{3}}}{M_{\mathrm{CaCO}_{3}}} \frac{M_{\mathrm{CO}_{3}}}{V}+0.5 H_{H} 10^{-\mathrm{pH}} \\
& +0.5 H_{O H} 10^{-[14-\mathrm{pH}]} \\
& K_{L} a=K_{L} a_{0} \cdot 1.024^{\left(T_{r(t)}-20\right)} \\
& r_{0_{2}(t)}=\mu_{0_{2}} \frac{1}{Y_{0_{2}}} C_{X(t)} \frac{C_{0_{2}(t)}}{K_{0_{2}}+C_{0_{2}(t)}} .1000 \\
& \mu_{X}=A_{1} e^{\left[\frac{E_{a 1}}{R\left(T_{r(t)}+273\right)}\right]}-A_{2} e^{\left[\frac{E_{a 2}}{R\left(T_{r(t)}+273\right)}\right]}
\end{aligned}
$$

The Equations 21 represents the cell concentration after filtrations of the bioreactor output.

$$
C_{X, C(t)}=\frac{0,999 \cdot F_{P(t)}}{F_{C}} \cdot C_{X(t)}
$$

The Equations 22 and 23 represent the recycle tank model.

$$
\begin{aligned}
& A_{R} \frac{d L_{R(t)}}{d t}=F_{A G(t)}+F_{C}-F_{D(t)}-F_{R(t)} \\
& A_{R} L_{R(t)} \frac{d C_{X, R(t)}}{d t}=F_{C} C_{X, C(t)}-F_{R(t)} C_{X, R(t)}-F_{D(t)} C_{X, R(t)}
\end{aligned}
$$


The constants and parameters used in this work are indicated in Table 5.

Table 5 - Parameters and constants of the ethanol plant model adapted from Nagy (2007) and Fonseca et al. (2014).

\begin{tabular}{|c|c|c|}
\hline $\mathrm{k}_{1}=7.5 \times 10^{-5}\left[\mathrm{~kg} \cdot \mathrm{U}^{-1} \cdot \mathrm{h}^{-1}\right]$ & $\mathrm{k}_{\mathrm{m}}=0.406\left[\mathrm{~kg} \cdot \mathrm{m}^{-3}\right]$ & $\mathrm{kg}_{\mathrm{g}}=1.22\left[\mathrm{~kg} \cdot \mathrm{m}^{-3}\right]$ \\
\hline $\mathrm{k}_{\mathrm{s}}=62.7\left[\mathrm{~kg} \cdot \mathrm{m}^{-3}\right]$ & $\mathrm{F}_{\mathrm{E}(0)}=5 \times 10^{-3}\left[\mathrm{~m}^{3} \cdot \mathrm{h}^{-1}\right]$ & $\mathrm{F}_{\mathrm{S}(0)}=1.82 \times 10^{-2}\left[\mathrm{~m}^{3} \cdot \mathrm{h}^{-1}\right]$ \\
\hline $\mathrm{F}_{\mathrm{A}(0)}=1.32 \times 10^{-2}\left[\mathrm{~m}^{3} \cdot \mathrm{h}^{-1}\right]$ & $\mathrm{C}_{\mathrm{S} 1(0)}=60.02\left[\mathrm{~kg} \cdot \mathrm{m}^{-3}\right]$ & $\mathrm{C}_{\mathrm{A}, \mathrm{i}(0)}=84\left[\mathrm{~kg} \cdot \mathrm{m}^{-3}\right]$ \\
\hline $\mathrm{C}_{\mathrm{E}, \mathrm{i}(0)}=2.65 \times 10^{5}\left[\mathrm{U} \cdot \mathrm{m}^{-3}\right]$ & $\mathrm{C}_{\mathrm{E}(0)}=7.2816 \times 10^{4}\left[\mathrm{U} \cdot \mathrm{m}^{-3}\right]$ & $\mathrm{L}_{\mathrm{S}(0)}=3.1189[\mathrm{~m}]$ \\
\hline $\mathrm{L}_{\mathrm{S}(\mathrm{t}) \operatorname{máx}}=3.65[\mathrm{~m}]$ & $\mathrm{C}_{\text {heat }, \mathrm{U}}=4.18\left[\mathrm{~J} \cdot \mathrm{g}^{-1} \cdot \mathrm{K}^{-1}\right]$ & $\mathrm{C}_{\text {heat }, \mathrm{r}}=4.18\left[\mathrm{~J} \mathrm{~g}^{-1} \cdot \mathrm{K}^{-1}\right]$ \\
\hline $\mathrm{A}_{S}=1.37\left[\mathrm{~m}^{2}\right]$ & $\mathrm{A}_{1}=9.5 \times 10^{8}$ & $\mathrm{~A}_{2}=2.55 \times 10^{33}$ \\
\hline$A_{F, j}=A_{F}=1\left[m^{2}\right]$ & $\mathrm{R}_{\mathrm{SX}}=0.607$ & $\mathrm{R}_{\mathrm{SP}}=0.435$ \\
\hline $\mathrm{E}_{\mathrm{a} 1}=5.5 \times 10^{4}\left[\mathrm{~J} \cdot \mathrm{mol}^{-1}\right]$ & $\mathrm{E}_{\mathrm{a} 2}=2.2 \times 10^{5}\left[\mathrm{~J} \cdot \mathrm{mol}^{-1}\right]$ & $\mathrm{H}_{\mathrm{H}}=-0.774$ \\
\hline $\mathrm{H}_{\mathrm{CO} 3}=0.485$ & $\mathrm{H}_{\mathrm{Cl}}=0.844$ & $\mathrm{H}_{\mathrm{Mg}}=-0.314$ \\
\hline $\mathrm{H}_{\mathrm{Ca}}=-0.303$ & $\mathrm{H}_{\mathrm{Na}}=-0.55$ & $\mathrm{H}_{\mathrm{OH}}=0.941$ \\
\hline $\mathrm{K}_{\mathrm{O} 2}=8.886\left[\mathrm{mg} \cdot \mathrm{L}^{-1}\right]$ & $\mathrm{K}_{\mathrm{P}}=0.139\left[\mathrm{~g} . \mathrm{L}^{-1}\right]$ & $\mathrm{K}_{\mathrm{P} 1}=0.07\left[\mathrm{~g} . \mathrm{L}^{-1}\right]$ \\
\hline $\mathrm{K}_{\mathrm{S}}=1.03\left[\mathrm{~g} . \mathrm{L}^{-1}\right]$ & $\mathrm{K}_{\mathrm{S}, 1}=1.68\left[\mathrm{~g} . \mathrm{L}^{-1}\right]$ & $\mathrm{K}_{\mathrm{T}}=3.6 \times 10^{5}\left[\mathrm{~J} \cdot \mathrm{h}^{-1} \cdot \mathrm{m}^{-2} \cdot \mathrm{K}^{-1}\right]$ \\
\hline $\mathrm{K}_{\mathrm{L}} \mathrm{a}_{\mathrm{o}}=38\left[\mathrm{~h}^{-1}\right]$ & $\mathrm{R}=8.31\left[\mathrm{~J} \cdot \mathrm{mol}^{-1} \cdot \mathrm{K}^{-1}\right]$ & $\mathrm{L}_{\mathrm{F}(0)}=1.1381[\mathrm{~m}]$ \\
\hline $\mathrm{L}_{\mathrm{F}(\mathrm{t}) \text { máx }}=1.33[\mathrm{~m}]$ & $\mathrm{V}_{\mathrm{j}}=0.05\left[\mathrm{~m}^{3}\right]$ & $\mathrm{Y}_{\mathrm{O} 2}=0.97\left[\mathrm{mg} \cdot \mathrm{mg}^{-1}\right]$ \\
\hline$\mu_{\mathrm{O} 2}=0.5\left[\mathrm{~h}^{-1}\right]$ & $\mu_{\mathrm{P}}=1.79\left[\mathrm{~h}^{-1}\right]$ & $\rho_{\mathrm{U}}=1,000\left[\mathrm{~g} . \mathrm{L}^{-1}\right]$ \\
\hline$\rho_{\mathrm{r}}=1080\left[\mathrm{~g} . \mathrm{L}^{-1}\right]$ & $\Delta \mathrm{Hr}=518[\mathrm{~kJ} / \mathrm{mol} \mathrm{O} 2]$ & $\mathrm{m}_{\mathrm{CaCO} 3}=100[\mathrm{~g}]$ \\
\hline $\mathrm{m}_{\mathrm{MgCl} 2}=100[\mathrm{~g}]$ & $\mathrm{m}_{\mathrm{NaCl}}=500[\mathrm{~g}]$ & $\mathrm{F}_{\mathrm{C}}=5\left[\mathrm{~L} \cdot \mathrm{h}^{-1}\right]$ \\
\hline $\mathrm{F}_{\mathrm{R}(0)}=1.8 \times 10^{-3}\left[\mathrm{~m}^{3} \cdot \mathrm{h}^{-1}\right]$ & $F_{P(0)}=2 \times 10^{-2}\left[\mathrm{~m}^{3} \cdot \mathrm{h}^{-1}\right]$ & $\mathrm{pH}=6$ \\
\hline $\mathrm{T}_{\mathrm{Ui}}=18\left[{ }^{\circ} \mathrm{C}\right]$ & $\mathrm{C}_{\mathrm{S}(0)}=4.197\left[\mathrm{~g} . \mathrm{L}^{-1}\right]$ & $\mathrm{MM}_{\mathrm{Cl}}=35.5\left[\mathrm{~g} \cdot \mathrm{mol}^{-1}\right]$ \\
\hline $\mathrm{MM}_{\mathrm{CO} 3}=60\left[\mathrm{~g} \cdot \mathrm{mol}^{-1}\right]$ & $\mathrm{MM}_{\mathrm{Na}}=23\left[\mathrm{~g} \cdot \mathrm{mol}^{-1}\right]$ & $\mathrm{MM}_{\mathrm{Ca}}=40\left[\mathrm{~g} \cdot \mathrm{mol}^{-1}\right]$ \\
\hline $\mathrm{MM}_{\mathrm{Mg}}=24\left[\mathrm{~g} \cdot \mathrm{mol}^{-1}\right]$ & $\mathrm{k}_{\mathrm{s}}=62.7\left[\mathrm{~kg} \cdot \mathrm{m}^{-3}\right]$ & $\mathrm{k}=7.5 \times 10^{-5}\left[\mathrm{~kg} \cdot \mathrm{U}^{-1} \cdot \mathrm{h}^{-1}\right]$ \\
\hline $\mathrm{k}_{\mathrm{m}}=0.406\left[\mathrm{~kg} \cdot \mathrm{m}^{-3}\right]$ & $\mathrm{kg}_{\mathrm{g}}=1.22\left[\mathrm{~kg} \cdot \mathrm{m}^{-3}\right]$ & $\mathrm{C}_{\mathrm{X}, \mathrm{R}(0)}=3\left[\mathrm{~kg} \cdot \mathrm{m}^{-3}\right]$ \\
\hline $\mathrm{C}_{\mathrm{X}, \mathrm{C}(0)}=5.142\left[\mathrm{~kg} \cdot \mathrm{m}^{-3}\right]$ & $\mathrm{A}_{\mathrm{R}}=0.2\left[\mathrm{~m}^{2}\right]$ & $\mathrm{L}_{\mathrm{R}(0)}=0.4917[\mathrm{~m}]$ \\
\hline $\mathrm{L}_{\mathrm{R}(\mathrm{t}) \operatorname{máx}}=0.55[\mathrm{~m}]$ & $\mathrm{F}_{\mathrm{R}(0)}=1.757 \times 10^{-3}\left[\mathrm{~m}^{3} \cdot \mathrm{h}^{-1}\right]$ & $\mathrm{F}_{\mathrm{AG}(0)}=3.57 \times 10^{-3}\left[\mathrm{~m}^{3} \cdot \mathrm{h}^{-1}\right]$ \\
\hline $\mathrm{F}_{\mathrm{D}(0)}=6.813 \times 10^{-3}\left[\mathrm{~m}^{3} \cdot \mathrm{h}^{-1}\right]$ & & \\
\hline
\end{tabular}

